\title{
PROBLEM SOLVING DALAM MENINGKATKAN KEMAMPUAN BERPIKIR KRITIS SISWA SMK
}

\author{
Resti Rima Safitri', Atrup², Guruh Sukma Hanggara ${ }^{3}$ \\ SMK Negeri 1 Watulimo ${ }^{1}$ \\ Universitas Nusantara PGRI Kediri2,3 \\ $\underline{\text { Restirimasafitri@gmail.com }}{ }^{1}$, atrup@unpkediri.ac.id²,$\underline{\text { kangguruh@gmail.com }}{ }^{3}$
}

\begin{abstract}
ABSTRAK
Penelitian ini dilatar belakangi hasil pengamatan dan pengalaman peneliti, bahwa pembelajaran di SMK Hang Tuah Kediri masih didominasi oleh keaktifan guru (konvensional). Berpikir kritis merupakan sebuah kemampuan yang seharusnya dimiliki oleh semua siswa SMK. Untuk itu butuh upaya untuk mengembangkannya, salah satu upaya yang bisa dilakukan melalui layanan BK adalah dengan menggunakan teknik problem solving. Sehingga peneliti memandang perlu untuk mengetahui keefektifan teknik problem solving dalam peningkatan kemampuan berpikir kritis siswa SMK. Penelitian ini menggunakan pendekatan one group pretest posttest design dengan subyek penelitian siswa SMK Pelayaran Hang Tuah Kediri kelas X Nautika A. Berdasarkan skor pretest, tingkat berpikir kritis siswa di SMK Pelayaran Hang Tuah perlu ditingkatkan. Hasil penelitian yang kemudian dianalisis dengan menggunakan uji Wilcoxon didapati hasil taraf signifikansi sebesar 0,007 dengan batas signifikansi $r_{\text {tabel }}$ sebesar $5 \%$ atau 0,05 . Dari hasil tersebut dapat dinyatakan bahwa teknik Problem Solving dalam Peningkatan Kemampuan Berpikir Kritis Siswa SMK Pelayaran Hang Tuah Kediri Kelas $X$ Nautika A Tahun 2015/2016 terbukti efektif".
\end{abstract}

Kata Kunci

berpikir kritis, problem solving

Cara mengutip: Safitri, R. R., Atrup \& Hanggara, G. S. (2018) Problem Solving dalam Meningkatkan Kemampuan Berpikir Kritis Siswa SMK. Jurnal Nusantara of Research, 5(2) 82-87.

\section{PENDAHULUAN}

Halpen (dalam Patmawati, 2011) memaparkan bahwa Berpikir kritis adalah strategi dan keterampilan kognitif yang diberdayakan untuk menetukan suatu tujuan. Keterampilan itu muncul ketika seseorang terlebih dahulu menetapkan tujuan atau sasaran, sehingga tujuan dan sasaran tersebut digunakan sebagai acuan untuk mempertimbangkan langkah dalam bertindak. Berfikir kritis sangat diperlukan ketika seseorang akan mengambil keputusan, memecahkan masalah, mempertimbangkan segala konsekuensi atau akibat, membuat kesimpulan dalam konteks tertentu. Menurut Paul (dalam Liberna, 2011) Berpikir kritis adalah kemampuan intelektual yang memungkinkan seseorang untuk terampil dan aktif dalam hal pemahaman, pengaplikasian, pensitesisan, serta pengevaluasian bermacam-macam informasi yang diakumulasikan dari berbagai pengamatan, refleksi, penalaran, komunikasi dan pengalaman yang dialaminya. Sedangkan Wingkel (dalam Patmawati, 2011) mendefinisikan bahwa berfikir kritis merupakan bentuk kemampuan dalam mengidentifikasi serta merumuskan masalah, menetapkan inti dari suatu informasi, mengidentifikasi perbedaan dan persamaan dari sesuatu, menggali relevansi informasi, kemampuan dalam membedakan antara pendapat dan fakta, membuat asumsi, mengendalikan prasangka, menimbang 
konsistensi berfikir, serta menarik kesimpulan secara bertanggung jawab berdasarkan data yang relevan disertai dengan pertimbangan dan perkiraan akibat yang akan ditimbulkan. Dari pengertian beberapa ahli di atas tentang definisi berpikir kritis, dapat disimpulkan bahwa berpikir kritis adalah sebuah proses yang penuh makna untuk mengarahkan dirinya sendiri dalam membuat suatu keputusan dengan cara menganalisis, mensintesakan, membandingbandingkan, membuat kesimpulan yang mendasar, dan mengevaluasi suatu informasi.

Kemampuan berpikir kritis merupakan kemampuan yang sangat penting bagi setiap orang yang berguna untuk pemecahan masalah dalam kehidupan, meneliti dan menganalisis informasi yang diterima disertai rasionalisasi agar tindakan yang akan dilakukan dapat berjalan secara benar (Liberna, 2011). Kemampuan berfikir kritis dapat memperkuat pemahaman tentang suatu masalah dan mencari solusi pemecahannya. Jika seseorang tidak memiliki kemampuan berpikir kritis dalam memecahkan masalah dan pengambilan keputusan, maka resiko pengambilan keputusan yang salah akan lebih besar.

Disinilah peranan pendidikan memberikan suatu konsep cara belajar yang efektif. Pendidikan dalam era modern semakin tergantung tingkat kualitas. Antisipasi dari para guru untuk menggunakan berbagai sumber yang tersedia mengatasi permasalahan yang dihadapi siswa untuk mempersiapkan pembelajaran yang dapat menumbuhkan cara berfikir kritis. Salah satu metode bimbingan yang tepat untuk meningkatkan cara berfikir kritis pada peserta didik adalah metode pembelajaran dengan menggunakan problem solving.

Majid (dalam Tijayanti, 2014: 175) menjelaskan bahwa problem solving merupakan cara dalam memecahkan masalah yang didahului dengan cara menstimulasi dan memberikan pengertian agar siswa memperhatikan, berfikir dan menelaah suatu masalah tersebut. Pendapat tersebut memberikan gambaran bahwa dengan beberapa tahap yang harus dilalui dalam proses pemecahan masalah melibatkan unsur-unsur kognitif seperti memperhatikan, menelaah, menganalisis, dan mengevaluasi, sehingga siswa akan terlatih mengembangkan kemampuan berpikir kritisnya. Pendapat tersebut juga ditunjang dengan penelitian yang dilakukan oleh Ika Tijayanti (2014) yang dilakukan di SMA Negeri 1 Suela lombok timur, dan menunjukan hasil bahwa siswa yang belajar dengan menggunakan problem solving cenderung lebih tinggi dari yang belajar dengan metode yang konvensional.

Kenyataan yang terjadi dilapangan, khususnya di SMK Pelayaran Hang Tuah Kediri, peserta didik cenderung malas untuk mengembangkan dan meningkatkan kemampuan berfikir mereka. Contohnya saat diberikan pelajaran, mereka hanya mendengarkan apa yang disampaikan oleh guru, dan tidak mencoba memahami apa yang disampaikan guru. Pada saat ujian atau ulangan harian, siswa mengungkapkan kembali materi yang telah mereka hafalkan dan tidak berusaha untuk mengembangkannya. Berpikir kritis merupakan sebuah kemampuan yang seharusnya dimiliki oleh semua siswa SMK. Untuk itu butuh upaya untuk mengembangkannya, salah satu upaya yang bisa dilakukan melalui layanan BK adalah dengan menggunakan teknik problem solving. Problem solving merupakan salah satu metode yang dipandang efektif untuk meningkatkan kemampuan berpikir tingkat tinggi, salah satunya berpikir kritis. Berdasarkan pemaparan masalah tersebut peneliti memandang perlu untuk 
mengetahui keefektifan teknik problem solving dalam meningkatkan kemampuan berpikir kritis siswa SMK.

\section{METODE}

Tujuan dari penelitian ini untuk mengetahui keefektifan teknik problem solving $(X)$ dalam meningkatkan kemampuan berpikir kritis $(Y)$ siswa SMK. Penelitian ini menggunakan pendekatan penelitian kuantitatif dengan subjek penelitian siswa kelas $X$ Nautika $A$, Tahun ajaran 2015/ 2016. Penelitian ini menggunakan desain pre-eksperimen jenis one group pretest-posttest dalam menganalisis dan mencapai tujuan penelitian. Penelitian ini menggunaka teknik purposive sampling dan jumlah sampel yang diambil ada 10 siswa. Instrument pengambilan data yang digunakan adalan skala kemapuan berfikir kritis yang dikembangkan sendiri oleh peneliti berdasarkan landasan teori yang relevan. Analisis data yang digunakan adalah uji beda dengan menggunakan uji Wilcoxon. Perhitungan yang digunakan untuk menguji hipotesis, jika signifikansi $a \leq 5 \%$, maka $\mathrm{H}_{0}$ ditolak dan $\mathrm{H}_{a}$ diterima. Artinya teknik problem solving efektif dalam meningkatkan kemampuan berpikir kritis siswa SMK Pelayaran Hang Tuah Kediri.

\section{HASIL}

Dalam menganalisis data, penelitian ini menggunakan uji wilcoxon dengan bantuan SPSS 16. Langkah pertama, adalah mencari hasil data dari pernyataan instrumen yang terdiri dari 23 pernyataan pretest dan posttest yang telah disebar pada siswa. Kemudian mengkategorikan skor hasil data dari instrumen kemampuan berpikir kritis yang telah diberikan saat sebelum diberi perlakuan dan sesudah diberikan perlakuan. Skor yang diberikan berdasarkan perhitungan secara analisis deskriptif diperoleh perhitungan interval sebagaimana pada tabel berikut:

Tabel 1. Konversi Skor Angket Pada Kualifikasi Penilaian

\begin{tabular}{cc}
\hline Rentang Skor & Kualifikasi Penilaian \\
\hline $75,5-92,00$ & Sangat Tinggi \\
\hline $58,00-74,5$ & Tinggi \\
\hline $40,50-57,00$ & Rendah \\
\hline $23,00-39,5$ & Sangat Rendah \\
\hline
\end{tabular}

Setelah selesai pemberian skor dilakukan oleh peneiti, kemudian ditabulasi dan disajikan daftar skor pretest dan posttest sebagai berikut:

Tabel 2. Skor nilai pretest-postest

\begin{tabular}{lcccc}
\hline No & Subjek & Nilai Pretest & Nilai Posttest & Keterangan \\
\hline 1 & A & 65 & 76 & Bertambah \\
\hline 2 & B & 53 & 59 & Bertambah \\
\hline 3 & C & 64 & 77 & Bertambah \\
\hline 4 & D & 66 & 78 & Bertambah \\
\hline 5 & E & 64 & 72 & Bertambah \\
\hline 6 & F & 61 & 73 & Bertambah \\
\hline 7 & G & 64 & 67 & Bertambah \\
\hline 8 & H & 68 & 80 & Bertambah \\
\hline 9 & I & 69 & 89 & Bertambah \\
\hline 10 & J & 80 & 92 & Bertambah \\
\hline
\end{tabular}


Dari skor yang disajikan diatas, dapat dilihat bahwa ada tingkat perbedaan kemampuan berpikir kritis siswa sebelum dan sesudah diberikan perlakuan menggunakan teknik problem solving. Kemudian untuk mendapatkan hasil perbedaan yang dapat mendukung data diatas, maka dilakukanlah pengujian menggunakan uji wilcoxon dibantu dengan aplikasi SPSS 16.

Tabel 3. Hasil Uji Hipotesis

\begin{tabular}{|c|c|c|c|c|}
\hline \multirow{5}{*}{ Posttest - Pretest } & & $\mathrm{N}$ & Mean Rank & Sum of Ranks \\
\hline & Negative Ranks & $0^{a}$ & .00 & .00 \\
\hline & Positive Ranks & $9^{b}$ & 5.00 & 45.00 \\
\hline & Ties & $1^{c}$ & & \\
\hline & Total & 10 & & \\
\hline & & \multicolumn{3}{|c|}{ Posttest - Pretest } \\
\hline \multicolumn{2}{|l|}{ Z } & \multicolumn{3}{|r|}{$-2.689^{a}$} \\
\hline \multicolumn{2}{|c|}{ Asymp. Sig. (2-tailed) } & \multicolumn{3}{|r|}{.007} \\
\hline
\end{tabular}

Dalam tabel dijelaskan bahwa tidak ada siswa yang mengalami penurunan tingkat kemampuan berpikir kritis sesudah diberikan perlakuan menggunakan teknik problem solving. Dari sepuluh sampel ada sembilan siswa yang mengalami peningkataan kemampuan berpikir kritis dan satu siswa tetap. Sedangkan dalam statistik 2-tailed terdapat signifikansi sebesar 0,007 yang itu lebih kecil dari 0,05. Berdasarkan hasil analisis data yang dilakukan diatas maka dapat diketahui bahwa Ho ditolak dan Ha diterima. Artinya teknik problem solving efektif dalam meningkatkan kemampuan berpikir kritis siswa SMK Pelayaran Hang Tuah Kediri.

\section{PEMBAHASAN}

Berdasar pada hasil penelitian, didapati bahwa teknik problem solving efektif dalam peningkatan kemampuan berpikir kritis siswa. Majid (dalam Tijayanti, 2014: 175) menjelaskan bahwa "problem solving merupakan cara memberikan pengertian dengan menstimulasi anak didik untuk memperhatikan, menelaah dan berfikir tentang suatu masalah untuk selanjutnya menganalisis masalah tersebut sebagai upaya untuk memecahkan masalah". Pendapat tersebut juga ditunjang dengan penelitian yang dilakukan oleh lka Tijayanti dengan judul "Keefektifan problem solving dalam pembelajaran PKN untuk pengembangan kemampuan berpikir kritis dan sikap nasionalisme" yang dilakukan di SMA Negeri 1 Suela lombok timur, mengemukakan hasil dari penelitian tersebut bahwa kemampuan berpikir kritis siswa yang belajar menggunakan teknik problem solving lebih tinggi dibanding dengan siswa yang belajar menggunakan metode konvensional.

Dengan teknik problem solving maka siswa diajarkan dan dibiasakan untuk mencari penyelesaian masalah dari kasus-kasus yang dibahas. Dengan belajar membahas masalahmasalah yang ada, maka kemampuan intelektual siswa akan dipicu dan dipacu menjadi lebih efektif. Salah satu kemampuan yang dibiasakan ketika seseorang dihadapkan pada masalah adalah ke-kritisanya dalam menganalisis dan mencari solusi dari setiap masalah. Dengan 
terbiasa kritis dalam menanggapi informasi dan masalah tesebut maka kemampuan berfikir kritis siswa dapat ditingkatkan.

Ditinjau dari setingnya yang dilakukan disekolah, hal ini tepat dilakukan karena lingkungan sekolah lebih dapat dikontrol dengan berbagai kebijakan-kebijakan tertentu. Hal tersebut diperkuat dengan pendapat Dewey (dalam Kurniawati, 2008: 2) mengatakan bahwa sekolah adalah tempat mengajarkan anak bahwa berpikir. Tidak hanya melalui bimbingan dan konseling saja, kemampuan berfikir kritis dapat dikembangkan. Kemampuan ini juga dapat dikembangkan dengan berbagai pelajaran yang menuntut siswa untuk memacu aktivitas berfikirnya.

\section{KESIMPULAN DAN SARAN}

Dari analisis hasil uji wilcoxon diperoleh data signifikansi 0,007 dengan signifikansi $r_{\text {tabel }}$ sebesar $5 \%$ atau 0,05. Dengan demikian dapat disimpulkan bahwa $h_{0}$ ditolak dan $h_{a}$ diterima yang artinya "Teknik problem solving Efektif dalam Peningkatan Kemampuan Berpikir Kritis Siswa SMK Pelayaran Hang Tuah Kediri Kelas X Nautika A, Tahun Pelajaran 2015/2016." Berdasarkan hasil penelitian ini maka peneliti memberikan saran untuk sekolah agar membuat inovasi yang didasarkan pada penelitian guna menumbuhkembangkan kemampuan berfikir kritis siswa. Untuk para konselor agar dapat menggunakan teknik problem solving dalam mengembangkan berbagai kemampuan intelktual salah satunya adalah kemampuan berfirik kritis. Saran lain untuk konselor adalah agar lebih kreatif dalam membuat terobosan-terobosan teknik BK yang dapat digunakan untuk mengembangkan kemampuan berfikir kritis, mengingat kemampuan ini merupakan kemampuan yang penting terutama dalam menjalankan aktifitas kehidupan yang penuh dengan permasalahan. Bagi peneliti selanjutnya untuk dapat meneliti pada seting sekolah selain SMK, disamping juga dapat menggunakan metode penelitian selain desain pre-eksperimen jenis one group pretestposttest, seperti menggunakan eksperimen-murni yang lebih terkontrol ancaman validitasnya, atau menggunakan desain lain seperti penelitian tindakan, sigle subject design (SSD) dan lain sebagainya. Lebih lanjut, peneliti selanjutnya dapat menggunakan teknik problem solving untuk mengembangkan aspek psikologi lainya selain kemampuan berfikir kritis, khususnya yang berada pada ranah kognitif siswa. Peneliti selanjutnya juga dapat mengembangkan kemampuan berfikir kritis siswa dengan menggunakan metode selain problem solving seperti diskusi kelompok, teknik Socrates, teknik bibliokonseling dan teknik BK lainya.

\section{DAFTAR RUJUKAN}

Kurniawati, E.F. 2008. Upaya Peningkatan Kemampuan Berpikir Kritis dan Keaktifan Siswa Melalui Penerapan Model pembelajaran Problem Solving Dalam pembelajaran Matematika. (Online). Tersedia: http://eprints.ums.ac.id, diunduh 15 November 2015 pukul 13.45.

Liberna, H. 2011. Peningkatan Kemampuan Berpikir Kritis Matematis Siswa Melalui Penggunaan Metode Improve Pada Materi Sistem Persamaan Linear Dua Variabel. (Online). Tersedia:http://www.unindra.ac.id, diunduh 12 November 2015 pukul 19.20. 
Patmawati, H. 2011. Analisis Keterampilan Berpikir Kritis siswa pada Pembelajaran Larutan Elektrolit dan Nonelektrolit dengan metode praktikum. (Online). Tersedia: http://repository.uinjkt.ac.ld, diunduh 12 November 2015 pukul 19.20.

Tijayanti, I. 2013. Keefektifan Metode Problem Solving Dalam Pembelajaran Pkn Untuk Pengembangan Kemampuan Berpikir Kritis Dan Sikap Nasionalisme Di SMA Negeri 1 Suela Lombok Timur. (Online). Tersedia: journal.uny.ac.id, diunduh 12 November 2015 pukul 19.04. 